\title{
Komparasi Perubahan Aspek Sosial Ekonomi Pada Penghuni Rumah Susun Pasca Penanganan SQuatter Di Kota Surakarta
}

\author{
KHIZAM DEBY KURNIAWAN \\ PROGRAM STUdi PERENCANAAN WILAYAH DAN KotA, \\ JURUSAN ARSITEKTUR, FAKULTAS TEKNIK \\ UNIVERSiTAS SEBElas MARET, SURAKARTA \\ ANA HARDIANA \\ PROGRAM STUdi PERENCANAAN WILAYAH DAN KoTA, \\ JURUSAN ARSITEKTUR, FAKULTAS TEKNIK \\ UNIVERSITAS SEBELAS MARET, SURAKARTA \\ RUFIA ANDISETYANA PUTRI \\ Program STUdi PERENCANAAN WILAYAH DAN KOTA, \\ JURUSAN ARSITEKTUR, FAKULTAS TEKNIK \\ UNIVERSITAS SEBELAS MARET, SURAKARTA
}

\begin{abstract}
City has main attraction for livable. The public has the view that a town has a comprehensive facilities, good accessibility, a broad field of work and so on. This matter causes population growth developments in the city, because people migrating to the city livelihood for the sake of more worthy. The increasing population is not balanced with the service especially in the field of housing the city settlement that will appear squatter. So that the squatter need to be handled, in general the handling of having two pattern handling squatter approach, that is a pattern on-site and off-site. On site pattern is a problem handling squatter location without move to another region but with providing a place of decent housing. While off site pattern is handling by moving the squatter to the regions and with the status of land was legal. In fact both handling is to improve social life and economic society. One of squatter handling in Surakarta is build a low cost apartment. The limited land in Surakarta is one of the reason to build a low cost apartment in the Surakarta City for handling squatter. Based on issues, this research knowing comparisons of socio-economic change in the low cost apartment post-handling squatter. The method is applicable in weighting analysis methods in identifying the social economy at low cost apartment in Surakarta. This result oh the research re the comparisons of socioeconomic aspects of changes on residents after handling squatter in Surakarta can be seen that in Begalon I low cost apartment experienced a medium increase, while in Begalon II low cost apartment and Semanggi low cost apartment increased low. So that the change in the economic and social aspect of Begalon I low cost apartment with on site pattern has the higher than Begalon II low cost apartment and Semanggi low cost apartment with off site pattern.
\end{abstract}

Keywords: low cost apartment, socioeconomic aspects, squatter

\section{PENDAHULUAN}

Sebuah kota memiliki daya tarik tersendiri untuk ditinggali. Masyarakat memiliki pandangan bahwa sebuah kota memiliki fasilitas yang lengkap, aksesibilitas yang baik, lapangan pekerjaan yang luas dan sebagainya. Hal ini menyebabkan pertumbuhan penduduk yang pesat di perkotaaan karena masyarakat berpindah ke kota demi penghidupan yang lebih layak. Masyarakat yang berpindah ke kota pada umumnya tidak memiliki pengalaman dan ketrampilan kerja yang cukup untuk tinggal di kota, tidak memiliki cukup 
modal untuk menyewa atau membeli

Semakin meningkatnya jumlah penduduk tidak diimbangi dengan peningkatan pelayanan kota khususnya di bidang perumahan permukiman sehingga akan muncul permukiman kumuh illegal (squatter). Sehingga squatter tersebut perlu ditangani, secara umum penanganan squatter memiliki dua pola pendekatan penanganan, yaitu pola onsite dan off-site (Hudalah, 2005). Penanganan on site disini maksudnya penanganan masalah squatter tanpa memindahkan lokasi ke daerah lain tetapi dengan menyediakan tempat tinggal yang layak huni. Sedangkan penanganan off site maksudnya penanganannya dengan memindahkan masyarakat yang tinggal di permukiman kumuh ilegal ke daerah lain yang lebih layak dan dengan status tanah yang legal. Pada hakikatnya kedua penanganan ini sama karena sama sama bertujuan untuk meningkatkan kehidupan sosial maupun ekonomi masyarakat.

Salah satu penanganan squatter di Kota Surakarta dengan membangun rumah susun. Semakin sempitnya lahan di Kota Surakarta menjadikan salah satu alasan pembangunan rumah susun di Kota Surakarta lebih diprioritaskan untuk menangani squatter. Hal ini dirasa langkah tepat untuk membebaskan Kota Surakarta dari squatter karena tidak membutuhkan lahan yang terlalu luas.

Berdasarkan isu yang sedang berkembang, penelitian ini ingin mengetahui komparasi perubahan aspek sosial ekonomi pada penghuni rumah susun pasca penanganan squatter di Kota Surakarta. Mengacu pada hal di atas, maka rumusan permasalahan dalam penelitian ini adalah bagaimanakah komparasi perubahan aspek sosial ekonomi pada penghuni rumah susun pasca penanganan squatter di Kota Surakarta?

\section{METODE}

Ruang lingkup wilayah dalam penelitian ini adalah Kota Surakarta tepatnya pada Rumah Susun Begalon I dan Rumah Susun Begalon II yang terletak di rumah (Khomarudin, 1997).

Kelurahan Panularan, Kecamatan Laweyan serta pada Rumah Susun Semanggi yang terletak di Kelurahan Semanggi, Kecamatan Pasar Kliwon. Ruang lingkup substansi adalah komparasi perubahan aspek sosial ekonomi pada penghuni rumah susun pasca penaganan squatter di Kota Surakarta yang meliputi adanya pengembangan ketrampilan oleh pemerintah, rasa aman, tingkat pendidikan, sistem kekerbatan, interaksi sosial, pengaruh lembaga kekerabatan terhadap masyarakat, partisipasi masyarakat, tingkat pendapatan, tingkat pengeluaran, jumlah tabungan, biaya untuk mencapai tempat kerja dan waktu tempuh ke tempat kerja.

Penelitian ini menggunakan metode analisa skoring. Analisis tersebut dapat dijabarkan sebagai berikut: (1) mengidentifikasi kondisi sosial dan ekonomi penduduk di lokasi rumah susun sebelum dan sesudah penanganan squatter di Kota Surakarta menggunakan teknik analisis skoring yang dibagai menjadi tiga kelas yaitu baik, sedang dan rendah dengan indikator penilaian yang telah dirumuskan; (2) mengidentifikasi perubahan aspek sosial ekonomi pada penghuni rumah susun pasca penanganan squatter di Kota Surakarta menggunakan teknik analisis skoring dengan mencari selisih skor masingmasing sub variabel setiap rumah susun sebelum dan seduah tinggal di rumah susun dengan membagi menjadi tujuh kelas berdasarkan perubahan skor sebelum dan sesudah tinggal di rumah susun; mengkomparasikan perubahan aspek sosial ekonomi pada penghuni rumah susun pasca penanganan squatter di Kota Surakarta. Komparasi ini didasari oleh perhitungan skoring perubahan aspek sosial ekonomi setiap rumah susun. 


\section{HASIL DAN PEIMBAHASAN}

Rumah Susun Begalon I memiliki skor 2 yang termasuk dalam kategori peningkatan sedang, sedangkan Rumah Susun Begalon II dan Rumah Susun Semanggi memiliki skor 1 atau yang termasuk dalam kategori peningkatan rendah (lihat lampiran 1). Hal ini juga dapat dilihat pada skoring pada sub variabel perubahan kualitas hidup pada Rumah Susun Begalon I memiliki skor lebih tinggi dibandingkan dengan Rumah Susun Begalon II dan Rumah Susun Semanggi sedangkan pada sub variabel kesejahteraan sosial pada ketiga rumah susun tersebut memiliki skor yang sama. Sehingga perubahan aspek sosial (lihat lampiran 2) pada Rumah Susun Begalon I yang merupakan penanganan on site memiliki peningkatan yang lebih tinggi dari Rumah Susun Begalon II yang merupakan penanganan off site tanpa mendekatkan tempat kerja dan Rumah Susun Semanggi yang merupakan penanganan off site dengan tempat kerja didekatkan sesuai dengan teori dari Hudalah (2005) yaitu penanganan on site memiliki kecenderungan mengalami peningkatan kehidupan sosial dan ekonomi masyarakat lebih tinggi dibanding dengan penanganan off site. Hal ini karena pada penanganan squatter secara on site tidak mengalami perpindahan lokasi tempat tinggal.

Karakteristik masing - masing rumah susun yang berbeda - beda yaitu Rumah Susun Begalon I merupakan penanganan on site dan Rumah Susun Begalon II yang merupakan penanganan off site tanpa mendekatkan tempat kerja serta Rumah Susun Semanggi yang merupakan penanganan off site dengan tempat kerja didekatkan, penanganan squatter pada ketiga rumah susun tersebut mengalami peningkatan pada variabel aspek sosial. Sehingga dapat dikatakan bahwa masing - masing rumah susun tersebut tujuan pembangunanya tercapai atau terlaksana karena mengalami peningkatan karena menurut Suharto (2010) menjelaskan bahwa pembangunan sosial sebagai suatu pendekatan pembangunan yang mempunyai tujuan untuk meningkatkan kualitas kehidupan manusia secara paripurna, yakni memenuhi kebutuhan manusia yang mulai dari kebutuhan fisik sampai sosial serta menurut Midgley (1995) menjelaskan bahwa pembangunan sosial ditujukan untuk meningkatkan taraf hidup seluruh masyarakat. Peningkatan taraf hidup masyarakat berkaitan dengan kesejahteraan masyarakat. Peningkatan aspek sosial ini dikarenakan adanya pengembangan ketrampilan oleh pemerintah sesudah tinggal di rumah susun, karena sebelum tinggal di rumah susun tidak memperoleh pengembangan ketrampilan oleh pemerintah, selain itu juga sesudah tinggal di rumah susun semua penghuni rumah susun sudah berinteraksi dengan penghuni rumah susun lain dengan baik dan semua masyarakat penghuni rumah susun berpartisipasi dalam kegiatan kelembagaan, karena sebelum tinggal di rumah susun interaksi dengan masyarakat kurang serta masih ada beberapa masyarakat yang tidak berpartisipasi dalam kegitan kelembagaan sehingga dengan adanya pengembangan ketrampilan oleh pemerintah dan interaksi serta partisipasi masyarakat dalam kelembagaan ini berdampak pada peningkatan aspek sosial.

Rumah Susun Begalon I, Rumah Susun Begalon II dan Rumah Susun Semanggi memiliki skor 1 atau yang termasuk dalam kategori peningkatan rendah (lihat lampiran 1). Hal ini juga dapat dilihat pada skoring pada sub variabel perubahan tingkat pendapatan dan ketersediaan lapangan kerja pada Rumah Susun Begalon I, Rumah Susun Begalon II dan Rumah Susun Semanggi memiliki skor yang sama. Sehingga perubahan variabel aspek ekonomi (lihat lampiran 3) pada Rumah Susun Begalon I, Rumah Susun Begalon II dan Rumah Susun Semanggi tidak sesuai dengan teori dari Hudalah (2005) yaitu penanganan on site memiliki 
kecenderungan mengalami peningkatan kehidupan sosial dan ekonomi masyarakat lebih tinggi dibanding dengan penanganan off site. Ketidaksesuaian dengan teori dari Hudalah ini dikarenakan perubahan tingkat pendapatan dan ketersediaan lapangan kerja pada ketiga rumah susun tersebut tidak mengalami peningkatan yang signifikan sehingga dalam hal ini peningkatan kondisi sosial ekonomi pada penanganan on site lebih tinggi daripada off site tidak berlaku karena sebagian besar penghuni rumah susun tidak mengalami perubahan pekerjaan sehingga perubahan tingkat pendapatan dan ketersediaan lapangan kerja dari ketiga rumah susun tersebut tidak mengalami perubahan yang signifikan.

Karakteristik masing - masing rumah susun yang berbeda - beda yaitu Rumah Susun Begalon I merupakan penanganan on site dan Rumah Susun Begalon II yang merupakan penanganan off site tanpa mendekatkan tempat kerja serta Rumah Susun Semanggi yang merupakan penanganan off site dengan tempat kerja didekatkan, penanganan squatter pada ketiga rumah susun tersebut mengalami peningkatan pada variabel aspek ekonomi. Sehingga dapat dikatakan bahwa masing - masing rumah susun tersebut tujuan pembangunanya tercapai atau terlaksana karena mengalami peningkatan karena menurut Todaro (2004) menjelaskan tujuan utama dari usaha-usaha pembangunan ekonomi adalah penghapusan atau pengurangan tingkat kemiskinan, penanggulangan ketimpangan pendapatan, dan penyediaan lapangan kerja dalam konteks perekonomian yang terus berkembang. Peningkatan aspek ekonomi ini dikarenakan jumlah tabungan yang mengalami peningkatan dari sebelum di rumah susun ada yang tidak mempunyai tabungan tetapi sesudah tinggal di rumah susun sebagian besar penghuni rumah susun memiliki tabungan meskipun jumlahnya sangat sedikit. Tetapi tingkat pendapatan, tingkat pengeluaran, biaya yang dikeluarkan untuk mencapai tempat kerja dan waktu tempuh ke tempat kerja cenderung tidak mengalami perubahan karena pekerjaan penghuni rumah susun juga tidak berubah. Sehingga dengan peningkatan jumlah tabungan ini berdampak pada peningkatan aspek ekonomi meskipun hanya mengalami peningkatan rendah.

Rumah Susun Begalon I memiliki skor 2 yang termasuk dalam kategori peningkatan sedang, sedangkan Rumah Susun Begalon II dan Rumah Susun Semanggi memiliki skor 1 atau yang termasuk dalam kategori peningkatan rendah (lihat lampiran 1). Hal ini juga dapat dilihat pada skoring pada variabel aspek sosial pada Rumah Susun Begalon I memiliki skor lebih tinggi dibandingkan dengan Rumah Susun Begalon II dan Rumah Susun Semanggi sedangkan pada variabel aspek ekonomi pada ketiga rumah susun tersebut memiliki skor yang sama. Sehingga perubahan aspek sosial ekonomi pada Rumah Susun Begalon I yang merupakan penanganan on site memiliki peningkatan yang lebih tinggi dari Rumah Susun Begalon II yang merupakan penanganan off site tanpa mendekatkan tempat kerja dan Rumah Susun Semanggi yang merupakan penanganan off site dengan tempat kerja didekatkan sesuai dengan teori dari Hudalah (2005) yaitu penanganan on site memiliki kecenderungan mengalami peningkatan kehidupan sosial dan ekonomi masyarakat lebih tinggi dibanding dengan penanganan off site. Hal ini karena pada penanganan squatter secara on site tidak mengalami perpindahan lokasi tempat tinggal sehingga tidak terlalu membutuhkan penyesuaian lagi dalam kehidupan sosial dan ekonomi.

Karakteristik masing - masing rumah susun yang berbeda - beda yaitu Rumah Susun Begalon I merupakan penanganan on site dan Rumah Susun Begalon II yang merupakan penanganan off site tanpa mendekatkan tempat kerja serta Rumah Susun Semanggi yang merupakan penanganan off site dengan tempat kerja didekatkan, penanganan squatter pada 
Khizam Debby dkk, Komparasi Perubahan...

ketiga rumah susun tersebut mengalami peningkatan pada aspek sosial ekonomi. Sehingga dapat dikatakan bahwa masing - masing rumah susun tersebut tujuan pembangunanya tercapai atau terlaksana karena mengalami peningkatan karena menurut Midgley (1995) pembangunan sosial ditujukan untuk meningkatkan taraf hidup seluruh masyarakat. Peningkatan taraf hidup masyarakat berkaitan dengan kesejahteraan masyarakat. Peningkatan taraf hidup masyarakat tersebut tidak dapat dilakukan tanpa adanya keterkaitan dengan pembangunan ekonomi. Jadi inti dari pikiran Midgley bahwa pembangunan sosial tidak akan dapat dijalankan tanpa adanya keterpaduan dengan pembangunan ekonomi. Pembangunan sosial dan ekonomi adalah dua hal yang saling berkaitan satu sama lain. Perencanaan dalam pembangunan sosial harus juga membuat perencanaan pembangunan ekonomi. Dari definisi tersebut maka dapat dikatakan bahwa untuk menciptakan suatu kondisi kehidupan yang sejahtera maka manusia harus dapat memenuhi kebutuhan hidupnya, permasalahan sosial dapat diatasi dengan baik dan manusia mempunyai kesempatan sosial untuk memiliki pekerjaan, mendapatkan pendidikan, ikut berpartisipasi dalam pembangunan dan berinteraksi dengan sesama manusia.

\section{KESIMPULAN}

Berdasarkan hasil analisis, komparasi perubahan aspek sosial ekonomi pada penghuni rumah susun pasca penanganan squatter di Kota Surakarta dapat dilihat bahwa pada Rumah Susun Begalon I mengalami peningkatan sedang, sedangkan pada Rumah Susun Begalon II dan Rumah Susun Semanggi mengalami peningkatan rendah. Sehingga perubahan aspek sosial ekonomi pada Rumah Susun Begalon I yang merupakan penanganan on site memiliki peningkatan yang lebih tinggi dari Rumah Susun Begalon II yang merupakan penanganan off site tanpa mendekatkan tempat kerja dan Rumah Susun Semanggi yang merupakan penanganan off site dengan tempat kerja didekatkan

\section{REFERENSI}

Hudalah, Delik. 2005. Pendekatan Pemberdayaan Dalam Penanganan Squatter: Sebuah Evaluasi Empiris. Bandung

Khomarudin. 1997. Menelusuri Pembangunan Perumahan dan Permukiman, Jakarta: Yayasan Real Estate Indonesia. Jakarta: PT. Rakasindo

Kurniawan, Khizam Deby. 2015. Komparasi Perubahan Aspek Sosial Ekonomi Pada Penghuni Rumah Susun Pasca Penanganan Squatter Di Kota Surakarta. Tugas AKhir Program Sarjana Perencanaan Wilayah dan Kota UNS

Midgley, James. 1995. Social Development: The Development Perspective in Social Welfare. London

Suharto, Edi. 2010. Analisis Kebijakan Publik. Bandung: Alfabeta

Todaro, Michael P. 2004. Ekonomi Pembangunan Di Dunia Ketiga. Jakarta: Erlangga 


\section{LAMIPIRAN}

\section{Lampiran 1}

\begin{tabular}{|c|c|c|c|}
\hline \multirow{2}{*}{$\begin{array}{c}\text { Sub } \\
\text { Variabel/Variabel }\end{array}$} & $\begin{array}{c}|c| \\
\text { Rumah Susun Begalon Setiap Rumah Susun } \\
\text { I }\end{array}$ & $\begin{array}{c}\text { Rumah Susun Begalon } \\
\text { II }\end{array}$ & $\begin{array}{c}\text { Rumah Susun } \\
\text { Semanggi }\end{array}$ \\
\hline $\begin{array}{c}\text { Perubahan Kualitas } \\
\text { Hidup }\end{array}$ & 2 & 1 & 1 \\
\hline Kesejahteraan Sosial & l & l & 1 \\
\hline Aspek Sosial & $\begin{array}{c}\text { 2 (Peningkatan } \\
\text { Sedang) }\end{array}$ & $\begin{array}{c}\text { 1 (Peningkatan } \\
\text { Rendah) }\end{array}$ & $\begin{array}{c}\text { 1 (Peningkatan } \\
\text { Rendah) }\end{array}$ \\
\hline $\begin{array}{c}\text { Perubahan Tingkat } \\
\text { Pendapatan }\end{array}$ & 1 & 1 & 1 \\
\hline $\begin{array}{c}\text { Ketersediaan } \\
\text { Lapangan Kerja }\end{array}$ & 1 & 1 & 1 \\
\hline $\begin{array}{c}\text { Aspek Ekonomi } \\
\text { Ispeningkatan } \\
\text { Rendah) }\end{array}$ & $\begin{array}{c}\text { 1 (Peningkatan } \\
\text { Rendah) }\end{array}$ & $\begin{array}{c}\text { 1 (Peningkatan } \\
\text { Rendah) }\end{array}$ \\
\hline $\begin{array}{c}\text { Aspek Sosial } \\
\text { Ekonomi }\end{array}$ & $\begin{array}{c}\text { 2 (Peningkatan } \\
\text { Sedang) }\end{array}$ & $\begin{array}{c}\text { 1 (Peningkatan } \\
\text { Rendah) }\end{array}$ & $\begin{array}{c}\text { 1 (Peningkatan } \\
\text { Rendah) }\end{array}$ \\
\hline
\end{tabular}

\section{Lampiran 2}

Tabel Skoring Perubahan Kualitas Hidup

\begin{tabular}{|c|c|c|c|c|c|c|c|c|c|c|c|c|}
\hline \multirow{4}{*}{$\begin{array}{l}\text { Perubahan } \\
\text { Kualitas } \\
\text { Hidup (Skor) }\end{array}$} & \multicolumn{12}{|c|}{ Nama Rusun } \\
\hline & \multicolumn{4}{|c|}{ Begalon I } & \multicolumn{4}{|c|}{ Begalon II } & \multicolumn{4}{|c|}{ Semanggi } \\
\hline & \multicolumn{2}{|c|}{ Sebelum } & \multicolumn{2}{|c|}{ Sesudah } & \multicolumn{2}{|c|}{ Sebelum } & \multicolumn{2}{|c|}{ Sesudah } & \multicolumn{2}{|c|}{ Sebelum } & \multicolumn{2}{|c|}{ Sesudah } \\
\hline & $\mathrm{F}$ & $\%$ & $\mathrm{~F}$ & $\%$ & $\mathrm{~F}$ & $\%$ & F & $\%$ & $\mathrm{~F}$ & $\%$ & $\mathrm{~F}$ & $\%$ \\
\hline 3 & 36 & $\begin{array}{c}34,3 \\
\%\end{array}$ & 66 & $\begin{array}{c}62,8 \\
\%\end{array}$ & 53 & $\begin{array}{c}36.1 \\
\%\end{array}$ & 75 & $51 \%$ & 95 & $48 \%$ & 108 & $54,5 \%$ \\
\hline 2 & 29 & $\begin{array}{c}27,6 \\
\%\end{array}$ & 39 & $\begin{array}{c}37,2 \\
\%\end{array}$ & 49 & $\begin{array}{c}33,3 \\
\%\end{array}$ & 65 & $\begin{array}{c}44,2 \\
\%\end{array}$ & 37 & $\begin{array}{c}18,7 \\
\%\end{array}$ & 86 & $43,4 \%$ \\
\hline 1 & 40 & $\begin{array}{c}38,1 \\
\%\end{array}$ & 0 & $0 \%$ & 45 & $\begin{array}{c}30,6 \\
\%\end{array}$ & 7 & $4,8 \%$ & 66 & $\begin{array}{c}33,3 \\
\%\end{array}$ & 4 & $2,1 \%$ \\
\hline Total & 105 & $100 \%$ & 105 & $100 \%$ & 147 & $100 \%$ & 147 & $100 \%$ & 198 & $100 \%$ & 198 & $100 \%$ \\
\hline
\end{tabular}

Keterangan :

F : Frekuensi

Tabel Skoring Kesejahteraan Sosial

\begin{tabular}{|c|c|c|c|c|c|c|c|c|c|c|c|c|}
\hline \multirow{4}{*}{$\begin{array}{c}\text { Kesejahteraa } \\
\text { n Sosial } \\
\text { (Skor) }\end{array}$} & \multicolumn{12}{|c|}{ Nama Rusun } \\
\hline & \multicolumn{4}{|c|}{ Begalon I } & \multicolumn{4}{|c|}{ Begalon II } & \multicolumn{4}{|c|}{ Semanggi } \\
\hline & \multicolumn{2}{|c|}{ Sebelum } & \multicolumn{2}{|c|}{ Sesudah } & \multicolumn{2}{|c|}{ Sebelum } & \multicolumn{2}{|c|}{ Sesudah } & \multicolumn{2}{|c|}{ Sebelum } & \multicolumn{2}{|c|}{ Sesudah } \\
\hline & $F$ & $\%$ & $F$ & $\%$ & $F$ & $\%$ & $F$ & $\%$ & $F$ & $\%$ & $F$ & $\%$ \\
\hline 3 & 93 & $\begin{array}{c}66,4 \\
\% \\
\end{array}$ & 114 & $\begin{array}{c}81,4 \\
\% \\
\end{array}$ & 142 & $\begin{array}{c}72,4 \\
\% \\
\end{array}$ & 165 & $\begin{array}{c}84,2 \\
\% \\
\end{array}$ & 204 & $\begin{array}{c}77,3 \\
\% \\
\end{array}$ & 224 & $79,6 \%$ \\
\hline 2 & 43 & $\begin{array}{c}30,7 \\
\%\end{array}$ & 26 & $\begin{array}{c}19,6 \\
\%\end{array}$ & 38 & $\begin{array}{c}19,4 \\
\%\end{array}$ & 31 & $\begin{array}{c}15,8 \\
\%\end{array}$ & 53 & $\begin{array}{c}20,1 \\
\%\end{array}$ & 40 & $20,4 \%$ \\
\hline 1 & 4 & $2,9 \%$ & 0 & $0 \%$ & 16 & 8,2 & 0 & $0 \%$ & 7 & $2,6 \%$ & 0 & $0 \%$ \\
\hline Total & 140 & $100 \%$ & 140 & $100 \%$ & 196 & $100 \%$ & 196 & $100 \%$ & 264 & $100 \%$ & 264 & $100 \%$ \\
\hline
\end{tabular}

Keterangan :

F : Frekuensi 


\section{Lampiran 3}

Tabel Skoring Perubahan Tingkat Pendapatan

\begin{tabular}{|c|c|c|c|c|c|c|c|c|c|c|c|c|}
\hline \multirow{4}{*}{$\begin{array}{l}\text { Perubahan } \\
\text { Tingkat } \\
\text { Pendapatan } \\
\text { (Skor) }\end{array}$} & \multicolumn{12}{|c|}{ Nama Rusun } \\
\hline & \multicolumn{4}{|c|}{ Begalon I } & \multicolumn{4}{|c|}{ Begalon II } & \multicolumn{4}{|c|}{ Semanggi } \\
\hline & \multicolumn{2}{|c|}{ Sebelum } & \multicolumn{2}{|c|}{ Sesudah } & \multicolumn{2}{|c|}{ Sebelum } & \multicolumn{2}{|c|}{ Sesudah } & \multicolumn{2}{|c|}{ Sebelum } & \multicolumn{2}{|c|}{ Sesudah } \\
\hline & $\mathrm{F}$ & $\%$ & $\mathrm{~F}$ & $\%$ & $\mathrm{~F}$ & $\%$ & $F$ & $\%$ & $\mathrm{~F}$ & $\%$ & $\mathrm{~F}$ & $\%$ \\
\hline 3 & 16 & $\begin{array}{c}15,2 \\
\%\end{array}$ & 15 & $\begin{array}{c}14,3 \\
\%\end{array}$ & 14 & $9,4 \%$ & 22 & $\begin{array}{c}14,9 \\
\%\end{array}$ & 17 & $8,6 \%$ & 35 & $17,6 \%$ \\
\hline 2 & 23 & $\begin{array}{c}21,9 \\
\%\end{array}$ & 38 & $\begin{array}{c}36,2 \\
\%\end{array}$ & 46 & $\begin{array}{c}31,3 \\
\%\end{array}$ & 43 & $\begin{array}{c}29,3 \\
\%\end{array}$ & 68 & $\begin{array}{c}34,3 \\
\%\end{array}$ & 83 & $41,9 \%$ \\
\hline 1 & 66 & $\begin{array}{c}62,9 \\
\%\end{array}$ & 52 & $\begin{array}{c}49,5 \\
\%\end{array}$ & 87 & $\begin{array}{c}59,3 \\
\%\end{array}$ & 82 & $\begin{array}{c}55,8 \\
\%\end{array}$ & 113 & $\begin{array}{c}57,1 \\
\%\end{array}$ & 80 & $40,5 \%$ \\
\hline Total & 105 & $100 \%$ & 105 & $100 \%$ & 147 & $100 \%$ & 147 & $100 \%$ & 198 & $100 \%$ & 198 & $100 \%$ \\
\hline
\end{tabular}

Keterangan :

F : Frekuensi

Tabel Skoring Ketersediaan Lapangan Pekerjaan

\begin{tabular}{|c|c|c|c|c|c|c|c|c|c|c|c|c|}
\hline \multirow{4}{*}{$\begin{array}{c}\text { Ketersediaan } \\
\text { Lapangan } \\
\text { Pekerjaan } \\
\text { (Skor) }\end{array}$} & \multicolumn{12}{|c|}{ Nama Rusun } \\
\hline & \multicolumn{4}{|c|}{ Begalon I } & \multicolumn{4}{|c|}{ Begalon II } & \multicolumn{4}{|c|}{ Semanggi } \\
\hline & \multicolumn{2}{|c|}{ Sebelum } & \multicolumn{2}{|c|}{ Sesudah } & \multicolumn{2}{|c|}{ Sebelum } & \multicolumn{2}{|c|}{ Sesudah } & \multicolumn{2}{|c|}{ Sebelum } & \multicolumn{2}{|c|}{ Sesudah } \\
\hline & $F$ & $\%$ & $\mathrm{~F}$ & $\%$ & $F$ & $\%$ & $\mathrm{~F}$ & $\%$ & $\mathrm{~F}$ & $\%$ & $\mathrm{~F}$ & $\%$ \\
\hline 3 & 49 & $70 \%$ & 53 & $\begin{array}{c}75,7 \\
\%\end{array}$ & 82 & $\begin{array}{c}83,7 \\
\%\end{array}$ & 85 & $\begin{array}{c}86.7 \\
\%\end{array}$ & 114 & $\begin{array}{c}86,4 \\
\%\end{array}$ & 116 & $87,8 \%$ \\
\hline 2 & 17 & $\begin{array}{c}24,3 \\
\%\end{array}$ & 13 & $\begin{array}{c}18,6 \\
\%\end{array}$ & 10 & $\begin{array}{c}10,2 \\
\%\end{array}$ & 7 & $7.2 \%$ & 14 & $\begin{array}{c}10,6 \\
\%\end{array}$ & 13 & $9,8 \%$ \\
\hline 1 & 4 & $5,7 \%$ & 4 & $5,7 \%$ & 6 & $6,1 \%$ & 6 & $6.1 \%$ & 4 & $3 \%$ & 3 & $2,4 \%$ \\
\hline Total & 70 & $100 \%$ & 70 & $100 \%$ & 98 & $100 \%$ & 98 & $100 \%$ & 132 & $100 \%$ & 132 & $100 \%$ \\
\hline
\end{tabular}

Keterangan :

F : Frekuensi 